\title{
Literasi Media Sosial pada Pustakawan Perguruan Tinggi Negeri
}

\author{
Desiana Ekasari Putri ${ }^{1}$; Fitri Mutia ${ }^{{ }^{*}}$ \\ ${ }^{1}$ Departemen Ilmu Informasi dan Perpustakaan, Fakultas Ilmu Sosial dan Ilmu Politik, Universitas Airlangga
}

*Korespondensi: fitri.mutia@ fisip.unair.ac.id

\begin{abstract}
Social media is one of the most popular information technology developments in society. Based on this phenomenon, librarians are required to have the social media literacy to use and manage information effectively and efficiently. This study aims to examine the social media literacy of librarians by using a conceptual framework initiated by Vanwynsberghe and Verdegem. The research approach used was quantitative. The sampling technique employed in this study was total sampling or saturated sampling. The number of respondents were 56 people that come from six state university libraries in Surabaya. The results indicate that librarians' social media literacy is in the high category (3.57), with each detail of practical competence and cognitive competence score is 3.66, while affective competence is in the medium category, with a score of 3.39. It can be seen that most of librarians in the State universities in Surabaya were able to operate social media through digital devices, identify, analyze and evaluate information on social media and view social media as a medium that can have a positive impact.
\end{abstract}

Keywords: social media literacy; university librarians; state university libraries; academic librarians

\begin{abstract}
Abstrak
Media sosial merupakan salah satu perkembangan teknologi informasi yang menjadi primadona di masyarakat. Pustakawan diharapkan memiliki literasi media sosial agar dapat menggunakan dan mengelola informasi secara efektif dan efisien. Penelitian ini bertujuan untuk mengetahui literasi media sosial yang dimiliki oleh pustakawan, dengan menggunakan kerangka konseptual yang digagas oleh Vanwynsberghe dan Verdegem. Metode penelitian yang digunakan yaitu kuantitatif. Teknik pengambilan sampel dalam penelitian ini yaitu dengan menggunakan total sampling atau sampling jenuh. Jumlah sampel dalam penelitian ini sebanyak 56 orang, yang tersebar di enam perpustakaan perguruan tinggi negeri di Surabaya. Hasil analisis data menunjukkan literasi media sosial yang dimiliki oleh mayoritas pustakawan perguruan tinggi negeri di Surabaya berada pada kategori tinggi $(3,57)$, kemampuan ini meliputi kompetensi praktis dan kompetensi kognitif memperoleh skor masing-masing sebesar 3,66 sedangkan kompetensi afektif berada pada kategori sedang, dengan skor sebesar 3,39. Mayoritas pustakawan perguruan tinggi negeri di Surabaya menguasai cara pengoperasian media sosial melalui perangkat digital, mengidentifikasi, menganalisis dan mengevaluasi informasi di media sosial serta memandang media sosial sebagai media yang mampu memberikan dampak positif.
\end{abstract}

Kata kunci: literasi media sosial; pustakawan perguruan tinggi; perpustakaan perguruan tinggi negeri

\section{PENDAHULUAN}

Kompetensi pustakawan merupakan salah satu aspek penting dalam mengelola perpustakaan. Hal tersebut dikarenakan masa depan perpustakaan bergantung pada nilai yang diciptakan oleh perpustakaan, mulai dari hubungan antara individu, tempat, pengetahuan dan teknologi untuk menciptakan platform untuk belajar, berpartisipasi, kreativitas, inovasi dan kesejahteraan (Walter W \& Snellman, 2015; Pakarya, Ibrahim \& Liem 2019). Selain itu, kompetensi pustakawan juga akan berpengaruh terhadap bagaimana ia berinteraksi kepada pengguna, dan turut mempengaruhi kepuasan pengguna (Shamsudin, Razak, \& Salem, 2018; Bian, et al., 2019). Seiring perkembangan zaman, pustakawan juga dituntut untuk senantiasa mengembangkan kompetensinya. Terlebih lagi di era di mana informasi beredar secara luas, dengan bantuan teknologi informasi, kini semua informasi dapat diakses di mana saja dan kapan saja. Salah satu perkembangan teknologi informasi yang kini berkembang di masyarakat yaitu media sosial (Corral de Zubielqui, Fryges \& Jones, 2017). 
Media sosial merupakan salah satu produk dari berkembangnya teknologi informasi yang bermula pada intranet dan jaringan pribadi (Mutula, 2013). Media sosial menjadi istilah pemersatu dari adanya fenomena media digital yang ada, seperti situs jejaring sosial, microblog, social news, blog comments and forums, bookmarking dan lain sebagainya (Ahenkorah-Marfo \& Akussah, 2016; Vanwynsberghe, et al., 2015), di mana media sosial sendiri telah menjangkau kehidupan pengguna, baik professional maupun non-professional (Sapkota \& Putten, 2018; Dlamini \& Johnston, 2018; Fasae \& Adegbilero-Iwari, 2016; Whiting \& Williams, 2013; Tench \& Jones, 2015; Henderson, et al., 2017; Chikandiwa, Contogiannis, \& Jembere, 2013). Hal ini didukung oleh penelitian yang dilakukan oleh Moreno et al. (2015) tentang penggunaan media sosial pada lebih dari 2710 para ahli komunikasi. Hasil penelitian menunjukkan bahwa lima alat komunikasi media sosial yang paling penting digunakan oleh para profesional: jaringan sosial ( 73,1 persen), video online $(66,9$ persen), ponsel aplikasi (59,1 persen), mikroblog (54,5 persen), dan berbagi foto (47,5 persen), sehingga dengan adanya media sosial, mereka dapat berkomunikasi satu sama lain dan dapat berbagi konten secara online melalui jaringan pribadi komputer atau ponsel digital (Bechmann \& Lomborg, 2012). Selain dampak positif, di sisi lain, ditemukan bahwa tingginya penggunaan media sosial, juga dapat menimbulkan dampak negatif (Tso \& Parikh, 2018).

Penggunaan media sosial yang tinggi di masyarakat, membuat perpustakaan perguruan tinggi mengadopsi media sosial di perpustakaan. Hal itu dibuktikan dengan digunakannya media sosial sebagai media promosi perpustakaan (Harrison et al., 2017). Media sosial yang digunakan oleh perpustakaan pun media sosial yang telah banyak dan sering digunakan oleh masyarakat, seperti facebook, twitter, Youtube dan instagram (Stvilia \& Gibradze, 2014; Bhavaraju, Beyney \& Nicholson, 2019, King, 2015). Meski begitu, implementasi media sosial di perpustakaan masih menghadapi kendala dan tantangan, seperti kegagalan daya (power value), jaringan yang buruk, kurangnya waktu (lack of time), dan kurang tertariknya beberapa pustakawan (Semode, Ejitagha, \& Baro, 2017), kompetensi Teknologi Informasi dan Komunikasi (TIK) pustakawan yang rendah (Ahmed \& Ur-Rehman, 2016) dan bahkan beberapa di antaranya, akun media sosial sudah tidak aktif lagi (Wasike, 2013).

Melihat fenomena ini, dibutuhkan pengetahuan dalam menggunakan media sosial oleh pustakawan, agar pustakawan dapat menggunakan dan mengelola informasi di media sosial secara efektif dan efisien. Literasi media sosial merupakan pengetahuan dan ketrampilan yang dibutuhkan untuk mengakses, menganalisis, mengevaluasi, dan membuat konten media sosial di berbagai konteks (Vanwynsberghe \& Verdegem, 2013). Sementara Moreno et al. (2015) mengungkapkan bahwa terdapat dua keterampilan utama atau pendekatan untuk penggunaan media sosial, yaitu keterampilan operasional dan strategis. Pendekatan operasional sendiri melibatkan pengaturan profil media sosial dan postingan konten, sedangkan pendekatan strategis berkaitan dengan mengembangkan taktik sebagai praktik dari penggunaan media sosial dengan tujuan yang jelas. Dengan demikian, komponen cara penggunaan media sosial harus mencakup kedua pendekatan.

Penelitian terkait literasi media sosial di kalangan pustakawan yang dilakukan di Flemish menunjukkan bahwa literasi media sosial pustakawan terbagi ke dalam beberapa kategori yaitu social media worker sebanyak 23,37 persen, social media laggards sebanyak 23,91 persen, social media literates sebanyak 28,26 persen dan social media spare-time users sebanyak 24,46 persen (Vanwynsberghe et al., 2015). Sementara di sisi lain Safira \& Irawati (2020) mengungkapkan bahwa terdapat hubungan antara literasi media sosial pustakawan dengan kualitas pemanfaatan eresources perpustakaan. Jika ditinjau dari struktur organisasi di perpustakaan, diketahui bahwa tidak semua pustakawan memiliki wewenang untuk mengoperasikan akun media sosial perpustakaan. Meski begitu, kompetensi dalam menggunakan media sosial tetap dibutuhkan oleh setiap pustakawan. Walaupun media sosial yang digunakan oleh individu tidak berkaitan dengan 
institusi atau perusahaan, namun hal tersebut masih memiliki potensi yang dapat memengaruhi citra institusi atau perusahaan (Walsh, Schaarschmidt, \& Kortzfleisch, 2016; Dreher, 2014). Hal tersebut dapat terjadi apabila dalam postingan tersebut berisi informasi atau konten yang dapat memberikan pengaruh negatif bagi institusi atau perusahaan, sehingga dalam hal ini pustakawan harus memiliki literasi dalam menggunakan media sosial. Agar postingan atau hal yang dilakukan dalam media sosial tidak merugikan instansi tempat ia bekerja dan mampu menyediakan konten yang bermanfaat dan informatif.

Oleh karena itu, penelitian ini bertujuan untuk mengetahui kompetensi literasi media sosial pustakawan dan sejauh mana pustakawan mengoperasikan media sosial secara efektif dan efisien dalam konteks individu, karena literasi media sosial yang dimiliki oleh pustakawan tentu akan berimplikasi pada pengelolaan media sosial yang ada di perpustakaan.

\section{METODE PENELITIAN}

Penelitian ini dilakukan dengan secara kuantitatif dengan total populasi sebesar 56 pustakawan. Teknik pengambilan sampel dalam penelitian ini menggunakan sampling jenuh atau total sampling (Sugiyono, 2014, 85). Penelitian ini dilakukan pada enam perpustakaan perguruan tinggi negeri di Surabaya, yang terdaftar di kemenristekdikti, yaitu perpustakaan Universitas Airlangga, Universitas Negeri Surabaya, Universitas Pembangunan Nasional Veteran Jatim, Institut Teknologi Sepuluh Nopember, Politeknik Elektronika Negeri Surabaya, dan Politeknik Perkapalan Negeri Surabaya. Sementara teknik pengumpulan data menggunakan kuesioner, studi pustaka, dan observasi. Selanjutnya untuk mengukur variabel, metode yang digunakan yaitu dengan menggunakan skala likert, di mana akan dibuat range pada setiap variabel, sebagai berikut ini:

$$
\text { Interval }=\frac{\text { Skor tertinggi-skor terendah }}{\text { banyaknya bilangan }}=\frac{5-1}{5}=0,8
$$

Dengan demikian, dapat diketahui tingkatan atau kategori jawaban dari masing-masing variabel, yaitu:

$\begin{array}{ll}\text { Kategori sangat rendah } & =1,00-1,80 \\ \text { Kategori rendah } & =1,81-2,60 \\ \text { Kategori sedang } & =2,61-3,40 \\ \text { Kategori tinggi } & =3,41-4,20 \\ \text { Kategori sangat tinggi } & =4,21-5,00\end{array}$

Data yang telah dikumpulkan, akan diolah menggunakan SPSS 21, dan hasil temuan akan disajikan berupa tabel dan dianalisis menggunakan statistik deskriptif.

\section{HASIL DAN PEMBAHASAN}

Berdasarkan data yang telah dihimpun, berikut merupakan identitas responden yang ditinjau dari jenis kelamin, usia dan latar belakang pendidikan: 
Tabel 1

Jumlah Responden Berdasarkan Jenis Kelamin

\begin{tabular}{ccc}
\hline Jenis Kelamin & Jumlah & Persentase \\
\hline Perempuan & 36 & 61,3 \\
Laki-Laki & 20 & 35,7 \\
Total & 56 & 100,0 \\
\hline
\end{tabular}

Berdasarkan tabel 1 menunjukkan bahwa jumlah responden perempuan sebanyak 61,3\% responden, sedangkan jumlah responden laki-laki sebanyak 35,7\% responden. Berdasarkan tabel tersebut, dapat disimpulkan bahwa jumlah responden yang berjenis kelamin perempuan lebih dominan jika dibandingkan dengan responden berjenis kelamin laki-laki.

Tabel 2

Jumlah Responden Berdasarkan Usia

\begin{tabular}{ccc}
\hline Usia & Jumlah & Persentase \\
\hline 21-30 Tahun & 9 & 16,1 \\
31-40 Tahun & 18 & 32,1 \\
41-50 Tahun & 17 & 30,4 \\
51-60 Tahun & 12 & 21.4 \\
Total & 56 & 100,0 \\
\hline
\end{tabular}

Berdasarkan tabel 2 dapat diketahui bahwa jumlah responden terbanyak yaitu responden yang memiliki usia sekitar 31-40 tahun, dengan jumlah sebanyak 32,1\% responden, sedangkan jumlah responden yang berusia 21 hingga 30 tahun memiliki jumlah paling sedikit yaitu sebanyak $16,1 \%$ responden.

Tabel 3

Jumlah Responden Berdasarkan Pendidikan Terakhir

\begin{tabular}{ccc}
\hline Pendidikan Terakhir & Jumlah & Persentase \\
\hline D2 & 3 & 5,4 \\
D3 & 9 & 16,1 \\
S1 & 38 & 67,9 \\
S2 & 6 & 10,7 \\
Total & 56 & 100,0 \\
\hline
\end{tabular}

Berdasarkan tabel 3 diketahui bahwa pendidikan terakhir responden yang paling banyak dalam penelitian ini yaitu responden dengan jenjang pendidikan S1, yang berjumlah sebanyak $67,9 \%$ responden. Sementara pada urutan terakhir yaitu responden dengan jenjang pendidikan D2, yang berjumlah 5,4\% responden. Berdasarkan tabel tersebut dapat diketahui bahwa pendidikan terakhir sebagian besar pustakawan didominasi jenjang pendidikan terakhir S1.

Penelitian ini didasarkan pada kerangka kerja literasi media sosial yang digagas oleh Vanwynsberghe \& Verdegem (2013). Kerangka kerja yang terdiri dari tiga kompetensi yaitu kompetensi praktis, kompetensi kognitif dan kompetensi afektif. Pada kompetensi praktis, responden akan diberikan pertanyaan yang merupakan penjabaran dari tiga indikator, yaitu kemampuan menggunakan perangkat digital, kemampuan mengoperasikan fitur-fitur di media sosial, serta kemampuan untuk menciptakan dan membagikan konten di media sosial. 
Tabel 4.

Hasil Kompetensi Praktis

\begin{tabular}{lccc}
\hline Indikator & Skor Total & $\begin{array}{c}\text { Total Skor } \\
\text { Rata-Rata }\end{array}$ & Kategori \\
\hline Kompetensi Praktis & 76,84 & 3,66 & Tinggi \\
\hline
\end{tabular}

Berdasarkan tabel 4 dapat diketahui bahwa secara keseluruhan, kompetensi praktis yang dimiliki oleh responden tergolong dalam kategori tinggi, di mana skor total dari kompetensi praktis ini yaitu sebesar 76,84, dengan total skor rata-rata 3,66. Hal ini dapat disimpulkan bahwa sebagian besar pustakawan memiliki kompetensi praktis.

Tabel 5.

Hasil Rekapitulasi Kompetensi Kognitif

\begin{tabular}{lccc}
\hline \multicolumn{1}{c}{ Indikator } & Skor Total & $\begin{array}{c}\text { Total Skor } \\
\text { Rata-Rata }\end{array}$ & Kategori \\
\hline What-Knowledge & 19,06 & 3,81 & Tinggi \\
How-Knowledge & 26,34 & 3,76 & Tinggi \\
Why-Knowledge & 20,52 & 3,42 & Tinggi \\
KOMPETENSI KOGNITIF & 21,97 & 3,66 & Tinggi \\
\hline
\end{tabular}

Sementara pada kompetensi kognitif, diukur dengan menggunakan 7 indikator, yaitu mengatur privasi di media sosial, mengetahui cara mengakses informasi, membandingkan sumber informasi, memeriksa keterbaruan informasi, memeriksa otoritas penulis, menentukan tujuan suatu informasi diciptakan dan menentukan kesimpulan sebuah informasi. Berdasarkan tabel 5, dapat diketahui bahwa secara keseluruhan, kompetensi kognitif berada pada kategori tinggi, baik dari komponen what-knowledge, how-knowledge dan why-knowledge. Pada komponen whatknowledge, diperoleh total skor sebesar 19,06 dengan total skor rata-rata sebesar 3,81. Pada komponen how-knowledge, diperoleh total skor sebesar 26,34 dengan total skor rata-rata 3,76. Pada komponen why-knowledge, diperoleh total skor sebesar 20,52 dengan total skor rata-rata 3,42 . Berdasarkan ketiga komponen tersebut diketahui bahwa total skor dari kompetensi kognitif yaitu sebesar 21,97 dengan total skor rata-rata 3,66.

Tabel 6

Hasil Rekapitulasi Kompetensi Afektif

\begin{tabular}{cccc}
\hline Indikator & Skor Total & $\begin{array}{c}\text { Total Skor } \\
\text { Rata-Rata }\end{array}$ & Kategori \\
\hline Struktur & 25,77 & 3,68 & Tinggi \\
Proses & 15,97 & 3,20 & Sedang \\
User (Pengguna) & 29,06 & 3,23 & Sedang \\
Komponen sikap & 23,60 & 3,37 & Sedang
\end{tabular}

\begin{tabular}{cccc}
\hline (Attitudinal Component) & & & \\
\hline Motivasi Disposisi & 23,71 & 3,31 & Sedang \\
Self-efficacy & 20,33 & 3,51 & Tinggi \\
Komponen Motivasional & 22,02 & 3,41 & Tinggi \\
(Motivational Component) & & & \\
Komponen Sikap (Attitudinal & & & Sedang \\
$\quad$ Component) & 23,60 & 3,37 & Tinggi \\
Komponen Motivasional & 22,02 & 3,41 & Sedang \\
(Motivational Component) & 22,81 & 3,39 & \\
\hline
\end{tabular}

Selanjutnya yaitu kompetensi afektif. Berdasarkan tabel 6 dapat diketahui bahwa secara keseluruhan, kompetensi afektif berada pada kategori sedang, dengan total skor 22,81 atau dengan 
total skor rata-rata sebesar 3,39. Lebih lanjut, kompetensi afektif merupakan kompetensi yang terdiri dari dua komponen, yaitu komponen sikap (attitudinal component) dan komponen motivasional (motivational component), di mana setiap komponen tersebut memiliki penjabaran masing-masing. Berdasarkan kedua komponen tersebut, dapat diketahui bahwa data tertinggi diperoleh dari komponen motivasional (motivational component), dengan total skor rata-rata sebesar 3,41 (kategori tinggi). Sementara data terendah diperoleh oleh komponen sikap (attitudinal component), dengan total skor rata-rata sebesar 3,37 (kategori sedang).

Tabel 7

Hasil Rekapitulasi Literasi Media Sosial

\begin{tabular}{lccc}
\hline Indikator Literasi Media Sosial & Skor Total & $\begin{array}{c}\text { Skor } \\
\text { Rata-Rata }\end{array}$ & Kategori \\
\hline Kompetensi Praktis & 76,84 & 3,66 & Tinggi \\
Kompetensi Kognitif & 26,34 & 3,66 & Tinggi \\
Kompetensi Afektif & 22,81 & 3,39 & Sedang \\
$\quad$ Total & 42,00 & 3,57 & Tinggi \\
\hline
\end{tabular}

Dari hasil temuan data yang diperoleh dan dipaparkan pada table 7 , diketahui bahwa mayoritas pustakawan perguruan tinggi negeri di Surabaya memiliki literasi media sosial yang tinggi. Hal ini dibuktikan dengan perolehan total skor rata-rata sebesar 3,57. Berikut merupakan penjelasan lebih lanjut mengenai literasi media sosial pustakawan di perguruan tinggi negeri di Surabaya.

\section{Kompetensi Praktis}

Vanwynsberghe \& Verdegem (2013) menyebutkan bahwa kompetensi praktis adalah kemampuan dalam penggunaan teknis alat dan aplikasi media sosial. Dalam hal ini kemampuan praktis dalam menggunakan media sosial, tidak hanya sekedar kemampuan dalam mengakses ke, dan pengoperasian media sosial serta konten di media sosial dengan perangkat digital, namun juga kemampuan untuk mengontrol layanan interaktif dan kreatif di media sosial.

Berdasarkan hasil yang telah dihimpun, diketahui bahwa sebagian besar pustakawan dapat mengoperasikan perangkat digital seperti smartphone, tablet, komputer dan laptop untuk mengakses media sosial. Dari keempat perangkat digital tersebut, perangkat smartphone merupakan perangkat digital yang memiliki skor yang paling tinggi, yaitu 4,27. Sementara dari hasil tersebut, juga dapat diketahui bahwa di antara perangkat digital yang ada, smartphone adalah perangkat digital yang menjadi primadona di kalangan pustakawan. Berdasarkan wawancara singkat kepada salah satu pustakawan, tingginya penggunaan smartphone tidak terlepas dari kemudahan yang didapatkan yaitu dapat diakses di mana pun dan kapan pun. Seperti yang diungkapkan oleh Tsetsi \& Rains (2017) bahwa desain smartphone membuat perangkat tersebut mampu menghadirkan ukuran yang lebih kecil dari perangkat lainnya. Hal inilah yang membuat smartphone menjadi perangkat yang fleksibel untuk dibawa.

Selanjutnya yaitu kemampuan dalam mengoperasikan fitur-fitur yang tersedia di media sosial. Berdasarkan data yang diperoleh, dapat diketahui bahwa sebagian besar pustakawan mampu untuk membuat akun media sosial tanpa bantuan orang lain. Skor rata-rata yang diperoleh pada pernyataan ini yaitu sebesar 3,88 yang berada pada kategori tinggi. Pembuatan akun pada media sosial merupakan salah satu hal utama yang harus dilakukan, karena sebelum dapat menuliskan atau menciptakan suatu konten di media sosial, maka seorang pustakawan terlebih dahulu harus memiliki akun. Hal ini dijelaskan oleh Vanwynsberghe, Boudry, \& Verdegem (2012) bahwa tanpa kemampuan praktis (dalam hal ini membuat akun di media sosial), maka individu tidak akan mampu untuk menganalisis, mengevaluasi, membagikan dan menciptakan 
konten di media sosial. Dari hasil penelitian diketahui bahwa mayoritas pustakawan mampu untuk mengunggah foto dan video, serta menandai orang lain pada postingan foto maupun video di media sosial. Selain itu, mayoritas pustakawan juga mampu untuk memposting review film, musik, buku, serta membuat quizz, polling dan kuesioner.

Berdasarkan data yang diperoleh, dapat disimpulkan bahwa kompetensi praktis yang dimiliki oleh sebagian besar pustakawan perguruan tinggi negeri berada dalam kategori tinggi. Kompetensi ini mendapatkan skor rata-rata tertinggi, jika dibandingkan dengan dua kompetensi lainnya. Secara keseluruhan, total skor rata-rata yang diperoleh untuk kompetensi praktis yaitu sebesar 3,66. Dari penjelasan di atas, dapat diketahui bahwa sebagian besar pustakawan dapat mengoperasikan media sosial dengan baik, seperti menciptakan dan membagikan konten, mengoperasikan fitur-fitur yang ada di media sosial, dan lain sebagainya. Hal ini sesuai dengan pernyataan yang disampaikan oleh Vanwynsberghe et al. (2015) bahwa kompetensi praktis tidak hanya sebatas pada kemampuan teknis, seperti mampu untuk mengoperasikan media digital tetapi juga dibutuhkan pengetahuan mengenai layanan interaktif dan kreatif pada platform media sosial. Begitu pula yang dinyatakan oleh Walsh, Schaarschmidt, \& Kortzfleisch (2016), bahwa untuk menggunakan media sosial, dibutuhkan keahlian dalam mengatur dan menggunakan semua fitur teknis di media sosial.

Apabila meninjau dari hasil penelitian sebelumnya, maka hasil temuan data dalam penelitian ini berbeda dari temuan sebelumnya. Pada penelitian yang dilakukan Vanwynsberghe et al. (2015), diketahui bahwa kompetensi praktis pustakawan yang ada di Flemish tergolong rendah. Hal ini menunjukkan bahwa pustakawan di perguruan tinggi negeri di Surabaya telah memenuhi standard kompetensi praktis. Kompetensi pustakawan dalam mengoperasikan fitur-fitur yang ada di media sosial tidak dapat dipungkiri bahwa hal tersebut merupakan hal pertama yang harus dikuasai apabila hendak mengoperasikan media sosial, karena kompetensi praktis merupakan langkah awal ketika mengakses media sosial.

\section{Kompetensi Kognitif}

Kompetensi kognitif merupakan salah satu prasyarat yang harus dimiliki oleh pengguna dalam menggunakan media sosial. Kompetensi kognitif pada penelitian ini terdiri dari 3 bagian, yaitu what-knowledge, how-knowledge dan why-knowledge. Sebagaimana yang diungkapkan oleh Potters dan Rogers (Vanwynsberghe \& Verdegem, 2013) yang membagi kompetensi kognitif menjadi tiga kategori yaitu what-knowledge, dan pengetahuan kritis (how-knowledge dan whyknowledge). Kompetensi kognitif sendiri merupakan kemampuan yang dibutuhkan untuk menganalisis dan mengevaluasi secara kritis motif dan tujuan yang membentuk konten yang dikonsumsi, bahasa pesan dan konteks di mana konten diproduksi (Vanwynsberghe, et al., 2015). Berdasarkan data yang telah diperoleh, total skor rata-rata untuk kompetensi kognitif berada pada kategori tinggi, dengan perolehan skor rata-rata sebesar 3,66.

Vanwynsberghe \& Verdegem (2013) mengutip dari James Potter dan Everett M. Rogers, mengungkapkan bahwa What-knowledge merupakan pengetahuan dengan kesadaran yang rendah, dan dapat dideskripsikan sebagai pengetahuan dasar yang dibutuhkan untuk mengakses teknologi media, konten atau layanan. Berdasarkan hasil penelitian di lapangan, diketahui bahwa komponen what-knowledge memperoleh skor rata-rata total sebesar 3,81. Sehingga dapat disimpulkan bahwa sebagian besar pustakawan telah memiliki pengetahuan what-knowledge.

Sementara itu, berdasarkan hasil temuan data di lapangan terkait kompetensi kognitif kritis, yaitu how-knowledge $(3,76)$ dan why-knowledge $(3,42)$, diketahui bahwa dibutuhkan pemikiran kritis untuk mendapatkan informasi yang aktual dan terpercaya. Isi informasi harus dianalisis dan dievaluasi agar tidak mudah percaya akan isi informasi, oleh karena itu dibutuhkan sikap skeptis dalam membaca informasi di media sosial. Hal ini dibuktikan yaitu untuk mendapatkan informasi 
yang terpercaya, pustakawan membandingkan informasi yang diperolehnya di media sosial dengan berbagai sumber, di antaranya yaitu dengan sumber dari portal berita online dan koran cetak. Dari kedua sumber tersebut, diperoleh hasil yang sama-sama tinggi, tetapi jika dilihat dari skor rata-rata yang diperoleh, skor rata-rata dari sumber portal berita online $(3,96)$ lebih tinggi dari sumber koran cetak $(3,66)$. Hasil tersebut didukung oleh hasil wawancara singkat yang dilakukan ke seorang pustakawan yang menyatakan bahwa ia lebih senang membandingkan dengan portal berita online, karena ia dapat mengaksesnya kapan saja dengan menggunakan perangkat digital yang dimilikinya. Sementara untuk koran cetak, sebagian pustakawan mengaku masih membaca koran cetak. Hanya saja untuk membandingkan informasi yang diperolehnya di media sosial dengan koran cetak, pustakawan tersebut menyatakan hal itu tidak sefleksibel pada saat menggunakan portal berita online. Penggunaan sumber pembanding berupa koran atau surat kabar, khususnya portal berita online, berkaitan erat dengan kredibilitas informasi yang ada di dalamnya. Hal ini sesuai dengan pernyataan Castell (2001) bahwa penggunaan surat kabar oleh masyarakat tidak terkurangi, meskipun kini telah terdapat berbagai macam sumber informasi. Surat kabar yang kini telah memiliki bentuk online atau yang sering dikenal dengan portal berita online, masih tetap menyediakan informasi yang kredibel, di mana hal tersebutlah unsur penting dalam membaca informasi.

Selain kedua sumber tersebut, pustakawan juga menggunakan beberapa sumber referensi, memeriksa keterbaruan informasi yang ada di media sosial, yaitu dengan memeriksa informasi itu dibuat. Lebih lanjut, mayoritas pustakawan juga menelusuri kapan peristiwa/informasi tersebut terjadi. Adapun cara untuk mengetahui apakah informasi yang ada di media sosial akurat atau tidak, yaitu dengan cara memeriksa otoritas penulis informasi tersebut. Hal ini didukung oleh salah satu pustakawan, ia menyatakan bahwa untuk mengetahui apakah penulis informasi itu memiliki otoritas atau tidak, cara yang dilakukan yaitu dengan menelusuri rekam jejak penulis di internet. Seperti yang diungkapkan oleh Castell (2001), bahwa jika individu ingin mengetahui kejadian yang ada di kota lain, maka internet akan memungkinkan individu tersebut untuk mendapatkan informasi. Selaras dengan pernyataan Castell, maka dengan menelusuri rekam jejak penulis, maka hal tersebut akan memungkinkan untuk mendapatkan informasi apakah penulis tersebut memiliki otoritas atau berkompeten di bidang tertentu.

Kompetensi kognitif tidak berhenti sampai pada kemampuan pustakawan untuk menilai akurasi atau kebenaran dari informasi. Akan tetapi, pustakawan juga harus mampu untuk menentukan apakah informasi tersebut merupakan informasi yang benar. Mengingat Informasi yang tersedia di media sosial telah berada pada taraf sangat berlimpah. Wihelm (2004, p. 21) menyebutkan bahwa di era informasi, informasi tersebar luas di berbagai media menyebabkan informasi yang kredibel dan dapat dipercaya semakin sulit untuk dibedakan. Hal ini dikarenakan setiap pengguna konten di media sosial, dapat sekaligus menjadi produsen konten di media sosial. Individu dapat dengan mudah menciptakan dan menyebarkan konten melalui media sosial, sehingga dibutuhkan kemampuan untuk memilah serta mengevaluasi informasi yang tersebar di media sosial. Hal ini lah yang menimbulkan individu dapat memperlihatkan eksistensinya melalui media internet, salah satunya yaitu media sosial. Antar individu berusaha untuk menunjukkan eksistensinya dengan cara menciptakan suatu konten di media sosial (contoh: vlog, instagram story, whatsapp story dan sebagainya). Melihat realitas tersebut, sebagian pustakawan berpendapat bahwa salah satu tujuan diciptakan dan disebarkannya informasi/konten di media sosial adalah untuk meningkatkan eksistensi penulis atau pembuat konten. Oleh karena itu dalam hal ini pustakawan dituntut untuk selektif dalam membaca dan memahami isi konten di media sosial, mengingat terdapat beragam motif pembuat konten dalam membuat konten.

Pustakawan dalam hal ini juga dapat menarik kesimpulan dari suatu informasi di media sosial, dengan berbagai cara, salah satunya yaitu dengan mengaitkan berbagai sumber refensi 
yang ada. Hal ini selaras dengan apa yang dinyatakan oleh Vanwynsberghe \& Verdegem (2013) bahwa kemampuan dalam analisis dan evaluasi merupakan dua hal yang saling berkaitan. Hal ini dikarenakan individu yang mampu untuk menilai keakuratan dan ketepatan informasi, juga harus dapat menilai kebenaran informasi, mengingat persebaran informasi kini sangat masif. Menelusuri rekam jejak penulis informasi, melihat informasi itu dibuat dan membandingkan informasi di media sosial merupakan beberapa cara agar dapat berfikir kritis. Menurut Ku et al. (2019), kebiasaan untuk menelusuri sumber berita memiliki keterkaitan dengan berfikir secara kritis. Sumber informasi yang kredibel, sangat penting untuk diperhatikan bagi pengguna yang ingin mengidentifikasi apakah informasi itu dapat dipercaya atau tidak.

Berkaitan dengan rekam jejak penulis, penulis merupakan salah satu komponen yang harus diperhatikan, apabila hendak memeriksa keakuratan informasi di media sosial, oleh karena itu pustakawan harus memiliki kemampuan dalam menentukan otoritas penulis informasi, apakah penulis tersebut memiliki otoritas di bidang tersebut, apakah penulis tersebut telah menuliskan informasi yang benar dan sebagainya. Hal ini seperti yang diungkapkan oleh Ashley, Maksi \& Craft (2013) dan Ku et al. (2019) bahwa individu harus memiliki kemampuan untuk menentukan apakah penulis memiliki kemungkinan mengkonstruksi isi berita secara berbeda, dengan tujuan untuk audien tertentu. Sementara itu, sumber informasi juga harus menjadi prioritas individu dalam memeriksa keakuratan informasi.

\section{Kompetensi Afektif}

Kompetensi Afektif merupakan komponen dalam literasi media sosial, yang memposisikan seseorang sebagai individu yang mampu untuk berkepsresi atau memiliki emosi. Dalam hal ini, kompetensi afektif mendapatkan skor rata-rata sebesar 3,39 dengan kategori sedang. Kompetensi afektif merupakan kompetensi yang terdiri dari dua komponen, yaitu komponen sikap (attitudinal component) yang memperoleh skor rata-rata sebesar 3,37 dan komponen motivasional (Motivational component) dengan skor rata-rata sebesar 3,41. Berdasarkan kedua komponen tersebut, dapat diketahui bahwa data tertinggi diperoleh dari komponen motivasional (motivational component). Sementara data terendah diperoleh oleh komponen sikap (attitudinal component). Berdasarkan hasil tersebut, dapat diketahui bahwa faktor motivasi dalam menggunakan media sosial memiliki nilai yang lebih tinggi jika dibandingkan dengan sikap terhadap karakteristik media sosial.

Komponen sikap dalam kompetensi afektif, terdiri dari struktur, proses dan user (pengguna). Sikap terhadap struktur media sosial mewakili pendapat individu tentang karakteristik khas media sosial seperti kreativitas, interaktivitas, dan pengembangan komunitas. Vanwynsberghe \& Verdegem (2013) menjelaskan bahwa apabila individu mengevaluasi komunikasi suatu kelompok dan menemukan obrolan yang terdapat di suatu halaman di media sosial sebagai sesuatu yang tidak baik, maka hal ini dapat memengaruhi sikap individu dalam menggunakan media sosial. Berdasarkan karakteristik khas media sosial yang telah disebutkan, adapun sikap yang ditunjukkan dalam berhubungan dengan media sosial, yaitu pustakawan menganggap media sosial merupakan media yang sangat menarik. Dari hasil tersebut dapat diketahui bahwa sebagian besar pustakawan memiliki sikap positif terhadap struktur yang ada di media sosial. Hal ini dibuktikan dengan total skor rata-rata yang diperoleh yaitu sebesar 3,68 dan berada pada kategori tinggi.

Sikap individu terhadap proses yang ada di media sosial, turut memengaruhi bagaimana individu tersebut bertindak di media sosial. Dilansir dari penjelasan Vanwynsberghe \& Verdegem (2013), apabila individu menganggap proses pertukaran informasi atau komunikasi sebagai sesuatu yang memiliki potensi negatif terhadap privasinya, maka salah satu upaya yang dilakukan adalah dengan mengatur pengaturan privasi. Berdasarkan hasil temuan data yang diperoleh, 
diketahui bahwa pustakawan dalam hal ini menjadi lebih berhati-hati ketika berhadapan dengan media sosial. Hal ini sesuai dengan pernyataan Vanwynsberghe et al. (2015), bahwa apabila pustakawan menemukan hal yang beresiko terhadap privasinya, maka ia akan lebih memperhatikan dan meningkatkan privasinya di media sosial.

Apabila dikaitkan dengan temuan data yang diperoleh, kepercayaan dan sikap pustakawan akan proses pertukaran informasi di media sosial bukan berarti pengetahuan yang dimiliki pustakawan rendah. Tetapi hal tersebut disebabkan karena sebagian pustakawan menganggap proses pertukaran informasi di media sosial tidak terjamin kerahasiannya. Jadi dapat disimpulkan bahwa kepercayaan akan proses pertukaran informasi di media sosial dapat dipengaruhi oleh beberapa faktor, dalam hal ini faktor penyebabnya yaitu kurang terjaminnya kerahasiaan dalam berkomunikasi di media sosial. Hal ini didukung dengan total skor rata-rata yang diperoleh berada pada kategori sedang, dengan total sebesar 3,20.

Sikap terhadap user (pengguna) berkaitan dengan praktik interaktivitas yang ada di media sosial. Ketika individu terlalu fokus pada tanggapan yang diberikan oleh orang lain, maka individu dapat merasa cemas atau khawatir ketika ia tidak mendapatkan balasan. Dalam hal ini, terdapat kemungkinan bahwa individu akan berfikir dua kali ketika akan memberikan komentar. Berdasarkan data yang telah diolah, diperoleh skor rata-rata sebesar 3,23 dan berada pada kategori sedang. Hal ini dapat diketahui bahwa beberapa pustakawan masih memiliki rasa khawatir ketika memberikan komentar, khususnya ketika komentar itu dirasa membutuhkan tanggapan. Hal ini sesuai dengan apa yang dinyatakan oleh Vanwynsberghe \& Verdegem (2013), apabila individu hanya terfokus pada respon orang lain, maka individu tersebut dapat merasakan cemas atau khawatir, namun terlepas dari hal tersebut, pustakawan tidak terlalu merasa cemas atau khawatir ketika akan memberi komentar.

Selanjutnya yaitu komponen motivasional (motivational component) terbagi menjadi dua yaitu motivasi disposisi (3,31) dan self-efficacy $(3,51)$. Motivasi disposisi terkait dengan penggunaan media sosial adalah kepedulian untuk mendapatkan respon positif (Vanwynsberghe \& Verdegem, 2013), sehingga individu berusaha untuk melakukan sesuatu dengan baik atau sempurna. Berdasarkan hasil temuan data yang diperoleh, diketahui bahwa respon positif merupakan hal yang penting bagi beberapa pustakawan, namun di sisi lain, sebagian pustakawan menyatakan bahwa respon negatif juga diperlukan sebagai bahan evaluasi kedepannya. Hasil yang diperoleh sesuai dengan apa yang dinyatakan oleh Hadewijch dan Pieter, bahwa untuk mendapatkan respon atau evaluasi positif, individu akan berusaha semakismal mungkin melaksanakan apa yang dilakukannya. Menurut Garmire \& Pearson (2006) sikap yang ditunjukkan oleh individu akan mengungkapkan motivasi yang dimilikinya. Berdasarkan hasil temuan, pustakawan berusaha untuk meningkatkan kemampuannya dengan beragam cara yang telah disebukan di atas, agar kemampuan dalam menggunakan media sosialnya, mendapatkan respon atau evaluasi positif. Maka dapat disimpulkan bahwa pustakawan memperlihatkan bahwa ia memiliki motivasi untuk ingin mendapatkan evaluasi positif dari orang lain.

Self-efficacy yang dimiliki oleh individu tentu akan memengaruhi bagaimana ia bersikap. Vanwynsberghe \& Verdegem (2013) menyatakan bahwa terdapat hubungan antara self-efficacy individu dengan aktivitas online. Dalam hal ini, self-efficacy yang dimiliki oleh pustakawan akan berpengaruh bagaimana ia bersikap dalam menggunakan media sosial, seperti usaha yang dilakukan, frekuensi penggunaan dan lain sebagainya. Penjelasan tentang self-efficacy berikut ini ditinjau dari 5 komponen yaitu performance experience, vicarious experience, imaginal experience, verbal persuation dan affective and physiological affectives (Gosselin \& Maddux, 2003). Apabila dikaitkan dengan penggunaan media sosial, maka pustakawan dengan self-efficacy yang tinggi cenderung akan selalu mencari jalan keluar ataupun bantuan, ketika ia merasa kesulitan atau hambatan. Pustakawan dengan self-efficacy yang tinggi juga cenderung tidak 
mudah untuk emosi ketika mengalami kesulitan dalam menggunakan media sosial. Di sisi lain, pustakawan dengan self-efficacy yang rendah, maka ia cenderung untuk mudah menyerah ketika mengalami kesulitan dalam menggunakan media sosial. Di dalam penelitian ini, self-efficacy memperoleh skor rata-rata sebesar 3,51 yang menunjukkan bahwa self-efficacy pustakawan perguruan tinggi negeri dalam menggunakan media sosial berada dalam kategori tinggi.

\section{SIMPULAN}

Literasi media sosial yang dimiliki oleh mayoritas pustakawan perguruan tinggi negeri di Surabaya berada dalam kategori yang tinggi, dengan total skor rata-rata sebesar 3,57. Skor ratarata tersebut diperoleh dengan rincian kompetensi praktis memperoleh skor rata-rata sebesar 3,66 (kategori tinggi), kompetensi kognitif memperoleh skor rata-rata sebesar 3,66 (kategori tinggi) dan kompetensi afektif diperoleh skor rata-rata sebesar 3,39. Hal ini menunjukkan bahwa mayoritas pustakawan perguruan tinggi negeri di Surabaya telah menguasai pengoperasian, pengaksesan media sosial dengan menggunakan media atau perangkat digital. Dalam hal ini, mayoritas pustakawan dapat mengidentifikasi, menganalisis dan mengevaluasi informasi atau konten yang ada di media sosial, kemudian yang terakhir yaitu sebagian besar pustakawan juga memiliki sikap dan perilaku yang positif terhadap karakteristik media sosial, yang berimplikasi pada pengaplikasian kompetensi praktis dan kompetensi kognitif yang dimiliki.

Di dalam penelitian ini terdapat keterbatasan pada populasi penelitian, sehingga bagi peneliti selanjutnya dapat memperluas populasi atau dapat menggunakan kerangka kerja lainnya yang relevan. Di dalam penelitian ini peneliti juga mengucapkan terima kasih kepada seluruh pihak yang telah membantu khususnya kepada pihak perpustakaan sehingga penelitian ini dapat berjalan dengan baik.

\section{DAFTAR PUSTAKA}

Ahenkorah-Marfo, M., \& Akussah, H. (2016). Changing the Face of Reference and User Services. Reference Service Review, Vol. 44 (3), 219-236. http://dx.doi.org/10.1108/RSR-01-20160001

Ahmed, S., \& Ur-Rehman, A. (2016). Perceptions and level of ICT Competencies: A survey of Librarians at public sectior universities in Khyber Pakhtunkhwa, Pakistan. Pakistan Journal of Information Management \& Libraries, Vol. 18 (1), 1-11.

Ashley, S., Maksi, A., \& Craft, S. (2013). Developing News Media Literacy Scale. Journalism \& Mass Communication Educator, Vol. $\quad$ 68(1), https://doi.org/10.1177\%2F1077695812469802

Bechmann, A., \& Lomborg, S. (2012). Mapping Actor Roles in Social Media: Different Perspecives on Value Creation in Theories of User Participation. News media \& Society, Vol. 15(5), 765-781. https://doi.org/10.1177\%2F1461444812462853.

Bhavaraju, S. K. T., Beyney, C., \& Nicholson, C. (2019). Quantitative analysis of social media sensitivity to natural disasters. International Journal of Disaster Risk Reduction, Vol. 39, 133. https://doi.org/10.1016/j.ijdrr.2019.101251.

Bian, L. K., Haque, A., Wok, A., \& Tarofder, A. K. (2019). The Effect of Customer Satisfaction on Customer Loyalty in The Motor Industry. Opcion Ano, 35(21), 947-963.

Castell, M. (2001). The Internet Galaxy: Reflections on the Internet, Business and Society. New York. USA: Oxford University Press.

Chikandiwa, S. T., Contogiannis, E., \& Jembere, E. (2013). The adoption of social media marketing in South African banks. European Business Review, Vol. 25(4), 365381. https://doi.org/10.1108/EBR-02-2013-0013. 
Corral de Zubielqui, G., Fryges, H., Jones, J. (2017). Social media, open innovation \& HRM: Implications for performance. Technological Forecasting \& Social Change, Vol 144, $334-$ 347. http://dx.doi.org/10.1016/j.techfore.2017.07.014

Dlamini, N. N., \& Johnston, K. (2018). The use of social media by South African organisations. Journal of Advances in Management Research, Vol. 15(2), 198-210. https://doi.org/10.1108/JAMR-05-2017-0063

Dreher, S. (2014). Social media and the world of work. Corporate Communications: An International Journal, Vol. 19(4), 344-356. doi:10.1108/ccij-10-2013-0087

Fasae, J. K., \& Adegbilero-Iwari, I. (2016). Use of social media by science students in public universities in Southwest Nigeria. The Electronic Library, Vol. 3(2), 213-222. http://dx.doi.org/10.1108/EL-11-2014-0205

Garmire, E., \& Pearson, G. (ed). (2006). Tech Tally: Aproaches to Assessing Technological Literacy. Washington DC. USA: The National Academies Press.

Gosselin, J. T. \& Maddux, J. E. (2003). Self-Efficacy. Handbook of Self and Identity. Ed. Mark R. Leary and June Price Tangney. New York. USA: The Guilford Press.

Harrison, A., Burress, R., Velasquez, Sarah., \& Schreiner, L. (2017). Social Media Use in Academic Libraries: A Phenomenological Study. The Journal Of Academic Librarianship, Vol. 43(3), 248-256. https://doi.org/10.1016/j.acalib.2017.02.014

Henderson, J., Wilson, A., Webb, T J., \& McCullum, D. (2017). The role of social media in communication about food risks Views of journalists, food regulators and the food industry. British Food Journal, Vol. 119(3), 453 - 467. http://dx.doi.org/10.1108/BFJ-07-2015-0272

King, D. L. (2015). Managing Your Librarys Social Media Channel. Library Technology Reports, Vol 51(1).

Ku, K. Y. L., Kong, Q., Song, Y., Deng, L., Kang, Y., \& Hu, A.. (2019). What Predicts Adolescents' Critical Thinking about Real-Life News? The Roles of Social Media News Consumption and News Media Literacy. Thinking Skills and Creativity, Vol 33, 1-25. https://doi.org/10.1016/j.tsc.2019.05.004

Moreno, A., Navarro, C., Tench, R., \& Zerfass, A. (2015). Does social media usage matter? An analysis of online practices and digital media perceptions of communication practitioners in Europe. Public Relations Review, Vol 41, 242-253. https://doi.org/10.1016/j.pubrev.2014.12.006

Mutula, S.M. 2013. Ethical Dimensions of the Information Society: Implications for Africa. In Information Ethics in Africa: Cross-cutting Themes. Pretoria: ACEIE, 29-42.

Pakarya, A. R., Ibrahim, R., \& Liem G. S. (2019). The Effect of Job Design and Job Description on Employee' Performance. Opcion, Ano, 35(21), 482-496.

Safira, F. \& Irawati, I. (2020). Hubungan Literasi Media Sosial Pustakawan Perguruan Tinggi dengan Kualitas Pemanfaatan e-Resources Perpustakaan. Jurnal Lentera Pustaka: Jurnal Kajian Ilmu Perpustakaan, Informasi dan Kearsipan, Vol 6(1), 1-12. https://doi.org/10.14710/lenpust.v6i1.25325.

Sapkota, K. N., \& Putten, J. V. (2018). Social Media Acceptance and Usage by business Communication faculty. Journal of Business and Professional Communication Quarterly, Vol 81(3), 328-350. https://doi.org/10.1177\%2F2329490618777818

Semode, F. D., Ejitgha, S. M., \& Baro, E. E. (2017). Social Networking sites: changing roles, skills and use by Librarians in Tertiary Institutions in Nigeria. Library Philosophy and practice (e-journal), 1-25.

Shamsudin, M.F., Razak, A.A., Salem, M.A. (2018). The Role of Customer Interactions Towards Customer Satisfaction in Theme Parks Experience. Opcion, Ano 34(16), 957-967. 
Stvilia, B., \& Gibradze, L. (2014). What do academic libraries tweet about and what makes a library tweet useful? Journal Library \& Information Science Research, Vol 36(3-4), 136141. https://doi.org/10.1016/j.lisr.2014.07.001

Sugiyono. (2014). Metodologi Penelitian Kuantitaitf, Kualitatif dan R \& D. Bandung: Alfabeta.

Tench, R., \& Jones, B. (2015). Social media: the Wild West of CSR communications. Social Responsibility Journal, Vol. 11(2), 290 - 305. http://dx.doi.org/10.1108/SRJ-12-2012-0157

Tsetsi, E., \& Rains, S. A. (2017). Smartphone Internet Access and Use: Extending the Digital Divide and Usage Gap. Mobile Media \& Communication, Vol 5(3), 239-255. https://doi.org/10.1177\%2F2050157917708329

Tso, H. H., \& Parikh, J. R. (2018). Embracing Social Media in The Era of Work-Life Integration. Clinical Imaging, Vol 58, 191-193. https://doi.org/10.1016/ j.clinimag.2019.07.011

Vanwynsberghe, H., Vanderlinde, R., Georges, A., \& Verdegem, P. (2015). The Librarian 2.0: Identifying a typology of librarians' social media literacy. Journal Of Librarianship and Information Science, vol 47(4), 283-293. https://doi.org/10.1177/0961000613520027

Vanwynsberghe, H., \& Verdegem, P. (2013). Integrating Social Media in Education. ClCWeb: Comparative Literature and Culture, Vol 15(3), 1-10.

Vanwynsberghe, H., Boudry, E. \& Verdegem, P. (2012). The Development of a Conceptual Framework of Social Media Literacy. Etmaal Van De Communicatiewetenschapeen, Proceedings. (pp. 1-18). Ghent, Belgium: Ghent University, Departement of Communication studies.

Walsh, G., Schaarschmidt, M., \& Kortzfleisch, H. V. (2016). Employee's company Reputationrelated Social Media Competence: Scale Development and Validation. Journal of Interactive Marketing, Vol 36, 46-59. https://doi.org/10.1016/j.intmar.2016.05.001

Walter W, P., \& Snellman, K. (2015). Public Libraries in a World of Knowledge. Tomorrow's libraries: future directions of the South Australian public library network, https://www.libraries.sa.gov.au/custom/web/PLS/SAPLN_tomorrows_libraries_digital_edit ion_3.pdf

Wasike, J. (2013). Social media ethical issues: role of a librarian. Library Hi Tech News, Vol. 30(1), 8-16. https://doi.org/10.1108/07419051311320922

Whiting, A., \& Williams, D. (2013). Why people use social media: a uses and gratifications approach. Qualitative Market Research: An International Journal, Vol. 16(4), 362-369. https://doi.org/10.1108/QMR-06-2013-0041 
Lentera Pustaka: Jurnal Kajian Ilmu Perpustakaan, Informasi dan Kearsipan, 6 (2) 2020, 145-158 